\title{
POEMAS PARA ANTONIO GAMONEDA
}

\section{EL ÁRBOL}

Entro en un árbol por su sombra siempre abierta, alegre y sin llamar, tranquilamente;

voy hacia el centro, subo o bajo, no lo sé,

y allí están todas las raíces, todos

los frutos esperándome, visibles y perfectos,

y el crecimiento de las ramas

es sólo una cuestión de pálpito y de luz,

que yo ahora puedo ver y oír... Hay nidos

abandonados, sucios, malolientes,

y extrañas criaturas de la noche. La luna

también está en el árbol y no es blanca.

Y hasta el viento circula muy oscuro,

se le puede tocar y no hace daño. Subo

o bajo, no lo sé: sé que camino.

Que pertenezco al árbol, lentamente. Me pierdo

en él, muy dentro, hasta que soy el árbol, fértil

y fuerte, el que quería para mí. Y ahora crezco

sin descansar, en la quietud ardiente 
224 Tropelías. Revista de Teoría de la Literatura y Literatura Comparada, 21 (2014)

Vicente Valero

del mediodía, cuando los pájaros me buscan,

entran en mí, reposan en su árbol.

\section{EL PÁJARO}

Eh, tú, pájaro de este lugar, sigue cantando o muéstranos para siempre el camino exacto y sin salida de nuestras quemaduras. ¿Cómo has podido hacer tu nido aquí, entre las ruinas blancas de nuestra vigilia y el mar envuelto en humo, indescifrable? Páramo de las palabras, donde el sol quema todos y cada uno de nuestros deseos -sí, donde yo al menos sé, ahora, que a veces cantas tú, oh pájaro de la misericordia.

De Vigilia en Cabo Sur, 1999

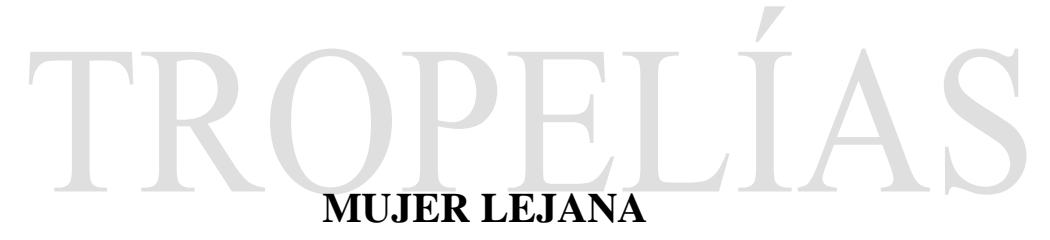

Como una sombra más de su pobreza,

de entre las ruinas blancas de la casa que vemos,

una mujer toda de negro y sola

sale a su mediodía inmenso, sin descanso,

con los ojos cerrados cada día.

Una mujer que no vemos muy bien, que busca

un cubo y se encarama, entre los gatos,

junto al granado viejo, y toca el mar,

el mar que está en el pozo, vacío, sin salida,

como una sombra más de este desierto.

Qué suerte ver llegar entonces a los pájaros,

tenerlos por aquí también, poder oírlos, 
como una sombra más en el dibujo, miren,

cerca de la mujer que no los ve,

bajo un cielo de arena, sobre el árbol.

Una mujer que está ya muerta, se diría,

aunque salga a tender la ropa muchas veces,

una mujer que no se ve, que la veríamos

sólo después de haber llovido algo,

con la mirada fría, distante, del invierno.

\section{PRINCIPIO DE IDENTIDAD}

Nosotros somos solamente

siempre lo que miramos: este bosque

y su camino azul somos nosotros,

esta lluvia distinta cada tarde,

que empapa muy adentro.

Somos la nube que pintamos, negra

sin más como la arena siempre

del anochecer... Somos

también el trueno y los relámpagos,

los ojos asustados

del animal que corre a su refugio.

No somos más que lo que busca ser

mirado y comprendido por nosotros:

este paisaje horizontal, el árbol 
226 Tropelías. Revista de Teoría de la Literatura y Literatura Comparada, 21 (2014)

Vicente Valero

\author{
y las piedras mojadas, \\ las huellas en el barro y la neblina \\ que no nos deja ver. \\ Y hasta somos también lo que no vemos: \\ aquello que pintamos muchas veces \\ sin saber cómo es, cómo será mañana, \\ después de la tormenta.
}

De Libro de los trazados, 2005

\title{
MIS MANOS EN ESTE BOSQUE
}

Mis manos también tienen su visión propia del bosque, han aprendido a abrir las páginas ocultas, a leer en ellas los textos invisibles. Palpan la oscuridad y la temperatura, el miedo y la esperanza.

Mis manos acarician el milagro del nido, su membrana nocturna. Acarician el aire que exhalan las raíces, la fuerza de los frutos nuevos, el rastro húmedo y transparente de los caracoles.

Tocan la luz pobre del musgo y el pálpito seco de las ramas rotas. Tocan la edad de la corteza y la consistencia de la resina. Tocan la humedad del color verde y el aliento oscuro de los escarabajos.

Acarician también los ojos del animal muerto y palpan en su mirada la sombra azul de todos los caminos, el agua deseada. Acarician el pulso fértil y amarillo de su descomposición.

Mis manos hablan entonces otro idioma: el que aprendieron palpando la textura del bosque, su misterio tangible.

De Días del bosque, 2008 